\title{
Unfair Trading Practices in Milk Supply Chain ${ }^{1}$
}

\author{
Lucia VARGOVA* - Jan POKRIVCAK** - Miroslava RAJCANIOVA**
}

\begin{abstract}
The objective of this paper is to identify the occurrence of unfair trading practices (UTPS) in Slovakia's milk agri-food supply chain. Based on survey data we aim to find out what UTPs are used at different stages of contract execution. We investigated the trade relationships between milk producers (dairy farms) and milk processors. Our results show that the weakest point of a business relationship, most exposed to UTPs is the phase of the contract negotiation. "No safeguard defined if the purchaser fails to fulfil the contract" is considered as the most common unfair trade practice by farmers. The highest incidence of UTPs is observed in the group of farms delivering more than 2 mil. litres of milk per year, especially when trading with big processor (dairies with annual sales more than 50 mil. EUR).
\end{abstract}

Keywords: milk supply chain, unfair trade practices, dairy farms

JEL Classification: Q02, Q13, Q18

DOI: https://doi.org/10.31577/ekoncas.2021.09.04

\section{Introduction}

In March 2019 the European Union (EU) has passed a directive on Unfair Trading Practices which prohibits ten practices in the EU agri-food supply chains while additional six practices are allowed only when buyer and supplier

* Lucia VARGOVA, Slovak University of Agriculture in Nitra, Faculty of Economics and Management, Department of Economic Policy, A. Hlinku 2, 94976 Nitra, Slovakia; e-mail: lucia.vargova@uniag.sk

** Jan POKRIVCAK - Miroslava RAJCANIOVA, Slovak University of Agriculture in Nitra, Faculty of Economics and Management, Department of Economic Policy, A. Hlinku 2, 94976 Nitra, Slovakia and University of West Bohemia, Faculty of Economics, Department of Economics and Quantitative Methods, Univerzitni 22, 30614 Pilsen, Czech Republic; e-mail: jpokrivcak@yahoo.com, miroslava.rajcaniova@uniag.sk

${ }^{1}$ We gratefully acknowledge financial support received from the Slovak Research and Development Agency under the contract No. APVV-18-0512 and VEGA 1/0768/20 (Slovak Republic) and GAČR project 19-18080S (Czechia). 
explicitly agree in advance in writing on their use in their trade relationship (Appendix 1). Central and Eastern European countries, including Slovakia, were strong proponents of the UTP legislation. The EU-wide UTP directive must be incorporated into national legislation. However, member states can pass on their own stricter measures on UTPs. In Slovakia, the first law on unfair trading practices was adopted in 2012, it was expanded in 2019 and amended in 2021 to cover more than 40 practices that are deemed unfair and became therefore outlawed (Appendix 2).

High interest in Slovakia by both farmers and policy makers to pass UTP legislation was correlated with the weakening bargaining position of farmers in the food supply chains. On the one hand, food supply chains are becoming more vertically coordinated to cope with market failures stemming from the existence of hold-up problems, uncertainty or asymmetric information or to guarantee food safety and quality, while on the other hand the position of farmers within the supply chain is getting weaker and their lowered bargaining power negatively impacts farmers' prices and contract terms with purchasers of their products or supplier of inputs (di Marcantonio, Ciaian and Castellanos, 2018).

The worsening of position of farmers within the food supply chain was caused by increased concentration in processing, input and retail sectors and globalization of retailers (Sexton, 2000; 2013; McCorriston, 2002). Furthermore, several reforms of the Common Agricultural Policy liberalized agricultural prices which enables stronger party in the food supply chain to transfer risk on weaker party. UTP legislation at both national and EU levels is an attempt by policy makers to react to unfavourable development of bargaining power of farmers, which affects both distribution of income and efficiency in the supply chains (Russo et al., 2020; Gow and Swinnen, 2000; Renda et al., 2014; Fałkowski et al., 2017).

UTPs might occur in all agricultural supply chains. Milk sector is, however, more likely to be affected by different types of unfair trading practices because milk is from the viewpoint of dairy farms a highly perishable product that needs to be delivered from the farm daily. Furthermore, milk producers have highly specific assets that cannot be redeployed to other sectors or even farms or with only high loss of value. These characteristics of dairy farms make them very vulnerable to unfair trading practices by purchasers of milk, mainly milk processors (di Marcantonio, Ciaian and Falkowski, 2020).

In Slovakia the total share of milk production in gross agricultural output in 2019 represented 13.7 percent (in value terms) making it relatively important commodity in the Slovak agriculture (SO SR, 2021). Milk production in Slovakia has been stagnating about 920 million litres annually since 2011. In 2020 it 
reached 917.3 million litres and this number is expected to increase to 924.1 million litres in 2021. While number of dairy cows declined from 156.1 thousand in 2011 to 121.7 thousand in 2020 and further decline is predicted to 117.5 thousand in 2021, yield has been increasing from 5772.8 litres of milk per cow in 2011 to 7536.8 litres per cow in 2020 with 7864.1 litres per cow predicted for 2021 (Repka, 2021).

Dairy farms in Slovakia sell milk mostly to dairies, in 2020 farms sold to dairies 808 million litres of milk, the remaining milk was consumed by animals on farms or sold directly to consumers (Repka, 2021). About 88 percent of produced milk farms sell to dairies. In Slovakia there are currently (June 2021) 377 primary milk producers and 37 purchasers of milk of which 36 reported the purchase of raw cow's milk (Agricultural Paying Agency, 2021). The concentration among milk purchasers is significantly higher than among milk producers. There are ten times more producers of milk than milk purchasers.

T a ble 1

Development of Numbers of Cows, Yield and Milk Production in Slovakia

\begin{tabular}{|l|c|c|c|c|c|c|c|c|c|c|c|}
\hline & $\mathbf{2 0 1 1}$ & $\mathbf{2 0 1 2}$ & $\mathbf{2 0 1 3}$ & $\mathbf{2 0 1 4}$ & $\mathbf{2 0 1 5}$ & $\mathbf{2 0 1 6}$ & $\mathbf{2 0 1 7}$ & $\mathbf{2 0 1 8}$ & $\mathbf{2 0 1 9}$ & $\mathbf{2 0 2 0}$ & $\mathbf{2 0 2 1} *$ \\
\hline $\begin{array}{l}\text { Number of cows } \\
\text { (1000 pcs) }\end{array}$ & 156.1 & 152.4 & 147.4 & 145.9 & 142.2 & 135.9 & 131.3 & 128.3 & 126.4 & 121.7 & 117.5 \\
\hline $\begin{array}{l}\text { Yield per cow } \\
\text { (1 per year) }\end{array}$ & 5772.8 & 6112.1 & 6149.7 & 6315.2 & 6536.5 & 6667.5 & 6937.0 & 7056.2 & 7158.0 & 7536.8 & 7864.1 \\
\hline $\begin{array}{l}\text { Milk production } \\
\text { (1000 000 1) }\end{array}$ & 901.3 & 931.5 & 906.7 & 921.1 & 929.5 & 906.1 & 910.7 & 905.4 & 905.0 & 917.3 & 924.1 \\
\hline
\end{tabular}

Note: *prediction, yield per cow and production of milk were originally expressed in kilograms and tons and converted to litres

Source: Repka (2021).

\section{Objectives}

The objective of this paper is to analyse the prevalence of UTPs in Slovakia's milk agri-food supply chain. We aim to control for different settings in which dairy farms operate in order to identify circumstances in which UTPs are more likely to occur. We investigate UTPs in trade relationships between milk producers (dairy farms) and milk processors across different stages of their contract negotiation and execution. We investigate the occurrence of the UTPs both in the formulation of the contracts as well as in the form of the breach of the existing contract.

We therefore aim not only to check whether the contractual conditions were complied with, but also whether UTPs were not directly included in the contractual conditions. 
The situation in Slovakia is specific as Slovak dairy farms are relatively large and more diversified than dairy farms in most of the Western European Member States of the European Union (Ciaian, Pokrivcak and Drabik, 2009; Guth, 2016). It is therefore interesting to study whether more diversified and larger milk producers in Slovakia face similar UTPs as small and specialized dairy farms in other EU countries. The situation in the Slovak agriculture has consolidated after initial decline of production that occurred after the collapse of communist regime (Pokrivcak and Ciaian, 2004). With EU accession Slovak dairy farms got access to a relatively stable EU market. However, milk supply chain is strongly dependent on good relationship between farmers and processors and market instability could affect the relationship between farmers and processors and can lead to UTPs.

Milk producers are on average significantly smaller than milk processors. It is therefore interesting to study whether larger farms face less UTPs than smaller farms. In the paper we also study whether the size of milk processors matters for the occurrence of UTPs. Furthermore, the European Union encourages farms to join producers' organizations to counterbalance the bargaining power of more concentrated processors (Michalek, Ciaian and Pokrivcak, 2018). Common agricultural policy of the EU supports farms that join a producer's organization to sell their production to processors jointly and to engage in joint investment or marketing. We therefore study how producers' organizations affect UTPs in dairy sector in Slovakia.

The paper is organized as follows. In the next section we provide a review of empirical literature on UTPs. It is followed by materials, methods and results sections. Final section wraps and concludes.

\section{Empirical Literature on the Incidence of UTPs}

The early studies, which dealt with the issue of UTPs, focused on one or few business practices and often did not target UTPs as such. This includes studies on costs or risk transferring (Sullivan, 1997; Boehlije, Hofing and Schroeder, 1999; Bloom, Gundlach and Cannon, 2000; Wever et al., 2012), delayed payments (Gow and Swinnen, 1998; Gow, Streeter and Swinnen, 2000), contract renegotiation (Huberman and Kahn, 1988; Hart and Tirole, 1988; Bolton, 1990), misuse of confidential information of a trading partner (Lederman, 2017), price pass through (Vavra and Goodwin, 2005; Pokrivcak and Rajcaniova, 2014; Gaudin, 2016), misuse of market power (Digal and Ahmadi-Esfahani, 2002; MacDonald and Key, 2012; Perekhozhuk et al., 2016) and other.

One of the first studies investigating the occurrence of UTPs, as a complex problem, was published by Davis and Reilly (2010). They focused on UTPs 
exercised by retailers to the detriment of their suppliers. Their results are based on a survey coordinated by UK Competition Commission on a sample of 456 suppliers and show that most of the suppliers $(37-48 \%)$ experienced delayed payments, additional payments for customers' complaints, additional services required by buyers and retroactive changes of price contracted.

An important survey was coordinated by the European Brands Association on a sample of 686 respondents from 15 EU member states and showed that $96.4 \%$ businesses from different supply chains had encountered UTPs. The following UTPs were found to be the most prevalent: business partner does not respect the terms stipulated in the contract and the buyer paid lower price than contracted while threatening the supplier with de-listing. The study also revealed that $65 \%$ of the firms experiencing UTPs are afraid to make a complaint because of fear that it would lead to sanctions or termination of the contract and loss of a business partner (CIAA-AIM, 2011).

Another survey trying to identify the UTPs in EU agri-food supply chains was published in the study of Copa-Cogeca (2013). The survey collected data from 434 respondents (farmers, agri-food cooperatives, processors and others) from 21 EU countries. According to their findings $94 \%$ of the respondents has experience with at least one UTP and $45 \%$ of them experienced all 17 investigated UTPs. Based on their findings, the most often UTPs used are payments for a customers' promotion and for other business activities of purchaser, unfair clauses in the contract, incomplete contracts lacking essential terms and conditions, and threatening the business partner with terminating their business relationship.

In 2015 the Bureau for Appraisal of Social Impact for Citizen Information analysed the banana value chains and the consequences of UTPs in several Latin American countries. Based on interviews of more than sixty actors from the banana industry they found out that the UTPs result from imbalances in market power between suppliers and retailers and the most impacted by UTPs are the small banana growers. The most often detected UTPs are unilateral contract changes, short-notice cancellations of orders, increased number of quality claims and additional fees for services like provision of banana boxes or transport to the buyer. The study also revealed the existence of the fear factor affecting small producers who do not take any action when confronted with UTPs (BASIC, 2015). Maglaras, Bourlakis and Fotopoulos (2015) studied the retailers' trading practices in Greek food supply chain. The most significant practices revealed from their survey with 398 food suppliers are upfront payments, unanticipated changes of agreements and negotiation pressures. Di Marcantonio, Ciaian and Castellanos (2018) reported results of the Joint Research Center investigation of UTPs in dairy sector in the EU. They carried out a survey in five EU countries 
and collected data from 1248 milk producers. Out of the 29 UTPs identified in the study, the most frequent unfair trading practices are no safeguard defined if the purchaser fails to fulfil the contract, not defined terms for contract cancellation and dairy specific investment required. The results also showed high incidence of UTPs in dairy sector, where $93 \%$ of the farmers faced at least one of the UTPs.

\section{Materials and Methods}

To analyse UTPs in milk supply chain in Slovakia we conducted a survey using personal interviews with milk producers. The sample of respondents consisted of farm managers (i.e., chairmen of cooperatives, company executives, farm managers). We prepared an electronic version of the questionnaire, which we sent out to the respondents. However, as the return rate on the questionnaire was low, we had to select some region of Slovakia and visit the farms personally to get answers to our questions. Personal meetings took place in the second half of 2018 and at the beginning of 2019 in two regions in Slovakia - the Nitra and Trnava regions. Prior to the meetings we contacted respondents and informed them about the purpose of the survey and subsequently provided them with the questionnaire. The list of primary milk producers in Slovakia is published by the Agricultural Paying Agency. At the end of 2018, a total of 115 holdings were registered in Trnava and Nitra regions as primary milk producers, which accounts almost one third of the total number of dairy producers in Slovakia. Due to the high share of milk producers and the higher representativeness of the sample, we opted for these two regions. We contacted all 115 respondents, but we only managed to reach 95 of them and $49 \%$ of them were willing to participate in our survey. The remaining producers expressed fear to share information with us. The fear factor is a common phenomenon that prevents the detection of UTPs as producers are often reluctant to talk about the trading practices and contracts for fear of losing their business partner. We conducted face-to-face meetings with managers of 47 dairy farms. Interviews took place in the premises of the farms and took approximately $45-60$ minutes per interview.

Respondents were asked to answer questions for the year 2017. The interview consisted of a total of 60 questions divided into three areas: Farm Characteristics, Contractual Relationships and Unfair Trade Practices. The division of UTPs was chosen based on a study of the Joint Research Center (di Marcantonio, Ciaian and Castellanos, 2018), which distinguishes among UTPs in the contract content, UTPs during the contract execution, and UTPs after the contract finalization. However, during the interviews with farm representatives, we also obtained information about UTPs not reported by di Marcantonio, Ciaian and Castellanos 
(2018) that enriched our list of UTPs by two more UTPs in the contract content, namely "Payment of the supplier for promotion, marketing, advertising" and "Other investment required to be conducted by the purchaser".

Collected data was used to test statistically the difference between small farms and large farms as well as between small and large processors with respect to the occurrence of the UTPs. The two-sample Wilcoxon rank-sum (Mann-Whitney) tests designed for different pairs of farms and dairies were used.

We tested the difference in average occurrence of UTPs between groups of farms trading directly with processors and farms trading via producer organizations using Mann-Whitney test for unpaired data.

\section{Results and Discussion}

Tables 2 and 3 provide selected farm descriptive characteristics of our sample. Slovak dairy farms are more diversified than specialized dairy family farms in the old EU Member States (EU-15). Slovak dairy farms are therefore relatively less dependent on their main buyer than specialized family farms.

Table 2

\section{Selected Farm Characteristics}

\begin{tabular}{|l|r|r|}
\hline & Total & \% of respondents \\
\hline Gender of farm manager & & \\
Male & 44 & 93.6 \\
Female & 3 & 6.4 \\
\hline Education of farm manager & 5 & \\
Secondary & 42 & 10.6 \\
University & & 89.4 \\
\hline Legal form & 35 & \\
Cooperative & 5 & 74.5 \\
Limited liability company & 4 & 10.6 \\
Joint stock company & 1 & 8.5 \\
Self-employed farmer & 2 & 2.1 \\
Other & & 4.2 \\
\hline Region & 19 & \\
Nitra & 28 & 40.4 \\
Trnava & & 59.6 \\
\hline Specialisation & 47 & \\
Milk production & 2 & 100.0 \\
Milk processing (e.g. cheese) & 26 & 4.3 \\
Meat production & 47 & 55.3 \\
Cultivation of cereals & 44 & 100.0 \\
Cultivation of other arable crops & 14 & 93.6 \\
Cultivation of orchards or vineyards & 2 & 29.8 \\
Other processing & 2 & 4.3 \\
Rural tourism & 8 & 4.3 \\
Other activities & & 17.0 \\
\hline
\end{tabular}

Source: Own processing. 
T a b le 3

\section{Descriptive Statistics}

\begin{tabular}{|l|r|r|r|r|}
\hline & Average & \multicolumn{1}{|c|}{ Max } & \multicolumn{1}{c|}{ Min } & \multicolumn{1}{c|}{ St. Dev. } \\
\hline Number of dairy cows (pcs) & 354.915 & 3200.000 & 78.000 & 464.538 \\
Number of other bovine animals (pcs) & 477.614 & 2700.000 & 92.000 & 487.321 \\
Total farm size (ha) & 1973.110 & 6900.000 & 270.000 & 1340.765 \\
Milk production (1000 1) & 3030.543 & 34867.388 & 385.785 & 5071.225 \\
Total sales from milk production (1000 eur) & 1694.739 & 5877.646 & 340.295 & 1523.855 \\
Total farm revenues (1000 eur) & 3039.548 & 7582.999 & 1588.877 & 2008.776 \\
\hline
\end{tabular}

Source: Own processing.

More than $74 \%$ of surveyed farms are cooperatives with milk production combined with additional activities mostly cultivation of cereals and other arable crops. The farm manager is mostly male $(93.6 \%)$ with university education (89.4\%). Farms produce on average 3030 thousands litres of milk per year, keeping 355 dairy cows with an average farm size of 1973 hectares of land.

Figure 1

\section{Number of Dairy Cows (a) and Milk Production (b)}

(a)

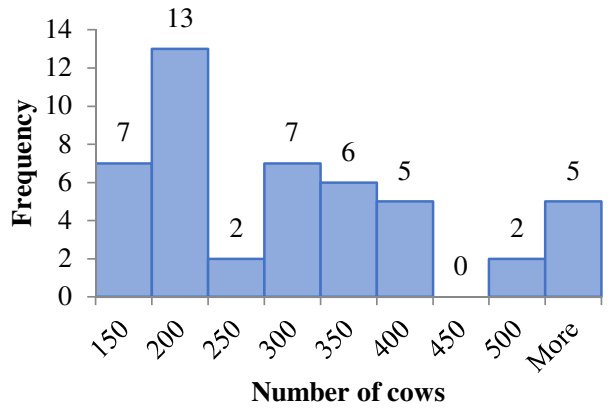

(b)

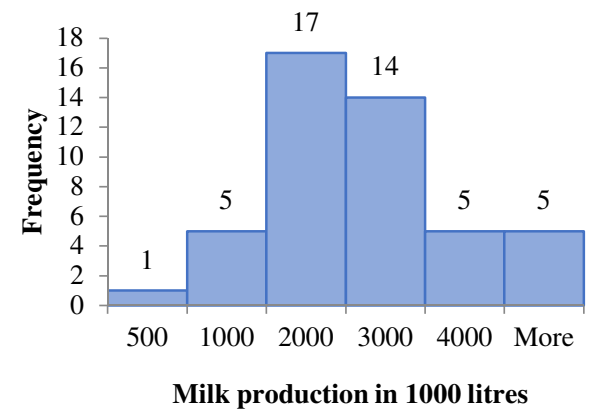

Source: Own processing.

Producers in our sample delivered $84.2 \%$ of dairy production directly to dairies and $10.6 \%$ was delivered to producer organisations. The smallest part of the production $(0.8 \%)$ was directly sold on the farm or in milk vending machines. $1.5 \%$ of the amount produced was own processing and about $3.3 \%$ of the milk was used for own consumption on the farm.

Tables 5, 6 and 7 list UTPs that were subject to our analysis. To make comparison with other Member States we have selected similar UTPs as the study of the Joint Research Center (di Marcantonio, Ciaian and Castellanos, 2018), which classifies UTPs as UTPs in the contract content, UTPs during contract execution, and UTPs after contract finalization. In our paper we keep the same division and 
furthermore we included two more UTPs in the contract content, namely "Payment of the supplier for promotion, marketing, advertising" and "Other investment required to be conducted by the purchaser".

Figure 2

\section{Structure of Milk Deliveries}

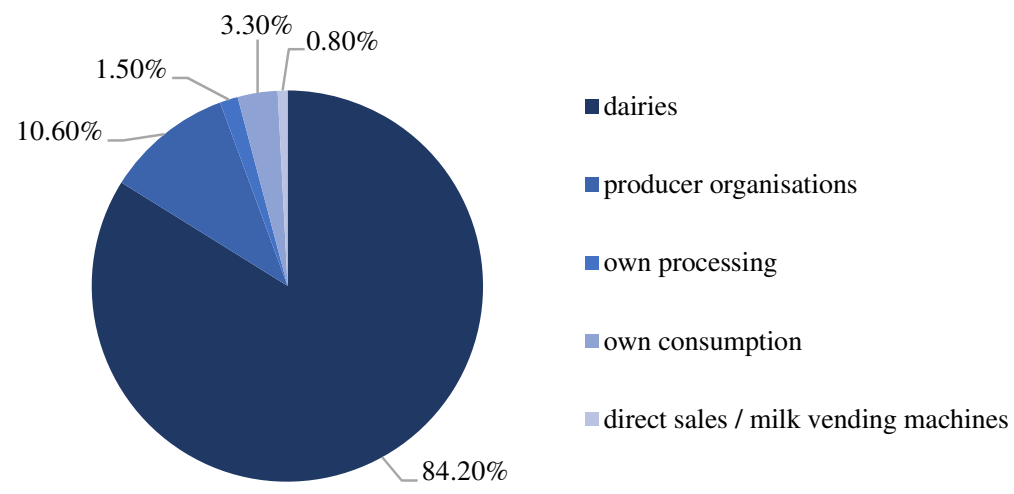

Source: Own processing.

Unfair trade practices can occur at different stages of the business relationship between suppliers and buyers. They may be a part of the contract, may occur during the contract execution or after the termination of the contractual relationship.

In Slovakia (specifically in regions of Trnava and Nitra) around $80 \%$ of dairy farms have individual contracts with their main purchaser of milk while $10 \%$ have contract with either a cooperative or producer organisation. All contracts have written form $(100 \%)$ and their duration typically exceeds one year $(73.16 \%)$ (Table 4).

T a ble 4

Contract Characteristics with the Main Purchaser (in \%)

\begin{tabular}{|l|c|}
\hline Existence of written contracts & 100.00 \\
Individual contract with the main purchaser & 80.09 \\
Duration of the contract & \\
12 months & 26.84 \\
more than 12 months & 11.46 \\
end is not defined & 61.70 \\
Frequency of contract renegotiation & \\
Once in a month or more & 34.04 \\
A couple of times in the year & 53.19 \\
Once a year & 8.51 \\
Less frequently than once a year & 4.26 \\
\hline
\end{tabular}

Source: Own processing. 
Tables 5, 6, and 7 depict the frequency of the occurrence of unfair trade practices at different stages of business relationships between milk producer and the main buyer, mainly milk processor. Our survey results show that milk producers are the most exposed to UTPs in the phase of the contract negotiation which is reflected in the unfavourable terms in the contract content. This result is fully in line with the findings of di Marcantonio, Ciaian and Castellanos (2018) who observed that the $96 \%$ of surveyed farmers reported at least one UTP in their contract with the main buyer, while UTPs during the contract execution and during the contract finalisation were much less often reported.

T a b le 5

Occurrence of UTPs in the Contract Content (in \%)

\begin{tabular}{|l|c|}
\hline No safeguard defined if the purchaser fails to fulfil the contract & 55.32 \\
Milk price not negotiated & 23.40 \\
Imposition of marketing/supply constraints & 17.02 \\
Purchaser has better contract cancellation terms & 8.51 \\
Purchaser can refuse or adjust milk delivery conditions & 6.38 \\
Payment of the supplier for promotion, marketing, advertising & 6.38 \\
Other investment required by the purchaser & 2.13 \\
Dairy specific investment required by the purchaser & 0.00 \\
\hline
\end{tabular}

Note: \% of respondents reporting UTP (respondents could report more than 1 UTP).

Source: Own processing.

"No safeguard defined if the purchaser fails to fulfil the contract" is considered by farmers as the most common unfair trade practice with respect to the contract content. The occurrence of this practice was confirmed by more than 50 percent of surveyed farm managers in Trnava and Nitra regions of Slovakia. According to them their contract with purchaser of milk does not include any safeguard clauses that would protect the producer against the purchaser's unfair behaviour. Furthermore, according to $8 \%$ of milk producers, purchasers had better contract cancellation terms than suppliers. 23 percent of farms did not have milk price stated in the contract. These practices became illegal after EU Directive had come into effect, however. Another frequently occurring unfair trading practice is the imposition of marketing/supply constraints (17\%). Here the producer is limited to sell milk to other processors/buyers, by pledging to deliver total production to one buyer, which imposes additional costs and risks on producers of milk. Our results are in line with the observation of di Marcantonio, Ciaian and Castellanos (2018) where "no safeguard defined if the buyer fails to fulfil the contract", better contract cancellation terms for purchasers, unilaterally set price by the buyer and imposition of marketing constraints were reported by $89.1 \%, 9.6 \%, 19.4 \%$ and $7.1 \%$, respectively, of surveyed dairy farmers across five study regions (Bayern in Germany, Galicia and Asturias in Spain, Normandie 
in France and Podlaskie in Poland). On the contrary in their study, four of the regions reported also diary specific investments required by the purchaser (10.7\% farms in Galicia, $32.1 \%$ in Normandie, $37.6 \%$ in Bayern, $8.2 \%$ farms in Podlaskie). In Slovakia there was no respondent reporting this UTP. Same result was obtained by di Marcantonio, Ciaian and Castellanos (2018) in Asturias region.

As follows from our survey, contract changes occur once a month or more often in $34 \%$ cases, $53 \%$ of the contracts are changed several times a year, in $8 \%$ of the cases contract conditions are renegotiated once a year and the rest of the respondents renegotiate conditions with the main buyer less frequently than once a year (Table 4).

Unilateral changes of contract prices and late payments are the main UTPs in the stage of contract execution. Unilateral change of contract prices by purchasers occurred in $21.28 \%$ of cases according to respondents. The risk of price changes is therefore transferred from purchasers to suppliers. About 10 percent of surveyed dairy farms suffer from delayed payments for milk deliveries from dairies. Delayed payments transfer income from producer to purchaser and in the long run they have a negative effect on investment which reduces overall welfare. When comparing our results with the findings for other regions in Europe we observe that di Marcantonio, Ciaian and Castellanos (2018) report much lower incidence of these UTPs. In Galicia and Asturias, the share of farmers reporting unilateral price changes is the highest among the five study regions, albeit relatively low, at $6.4 \%$ and $4.4 \%$ of farmers, respectively. In Bayern, unilateral price change affected $1.7 \%$ farmers and in Podlaskie only $0.4 \%$ farmers. The incidence of delayed payments is even less present (only $0.1 \%$ across the five regions). Late payments have long bothered farmers in Slovakia. Gow and Swinnen (2000) reported the average payment delay of 100 days by food processors to farms supplying raw materials in Slovakia in the early transmission period in 1994 and 1995.

Table 6

Occurrence of UTPs during the Contract Execution (in \%)

\begin{tabular}{|l|r|}
\hline The price was changed unilaterally & 21.28 \\
Dairy paid with delay & 10.64 \\
The required quality was changed unilaterally & 4.26 \\
Dairy paid lower price than contracted & 2.13 \\
The required quantity was changed unilaterally & 2.13 \\
Dairy required milk quality or quantity different than agreed & 0 \\
Dairy did not collect milk or refused to accept milk delivery & 0 \\
Dairy imposed additional fees/deductions & 0 \\
Other terms of contract were not respected* & 0 \\
\hline
\end{tabular}

Note: \% of respondents reporting UTP (respondents could report more than 1 UTP), * Other terms of contract include e.g. credit, information provision, milk collection, sanitary/veterinary services.

Source: Own processing. 
$80 \%$ of producers did not take any action when facing late payments. This can be attributed to the presence of the so-called fear factor. Fear factor is closely linked to the fact that dairy producers find it difficult to change the main buyer, because there are no other dairies in the neighbourhood (13\% of the cases), farmers find it risky to start to cooperate with new dairy (36\%), other dairies are not reliable $(6 \%)$, other dairies have higher milk quality requirements $(6 \%)$, membership shares would be paid with long delay (8\%) and other reasons. In the period under review, there were also cases where the dairy paid less than the contracted amount $(2.13 \%)$, or the required quantity $(2.13 \%)$ or the quality was unilaterally changed $(4.26 \%)$.

In the context of termination of a contract, the unfair trade practice refers to the unilateral termination of the contract before expiration encountered by $6.38 \%$ of farmers. In the EU survey it was only $1.2 \%$ of farmers facing unilateral contract cancellation before expiration (di Marcantonio, Ciaian and Castellanos, 2018).

T a ble 7

Occurrence of UTPs after the Contract Finalization (in \%)

\begin{tabular}{|l|c|}
\hline Contract was ended by the purchaser unilaterally before expiration & 6.38 \\
\hline
\end{tabular}

Note: \% of respondents reporting UTP.

Source: Own processing.

In general, the occurrence of unfair trade practices is quite frequent. $40.4 \%$ of respondents faced a single unfair trade practice during their contractual relationship with their buyer, $34 \%$ of the respondents confirmed two practices, $10.6 \%$ respondents suffered from three, and $4.3 \%$ of the farms reported six types of different UTPs. In total $89.36 \%$ of the sampled farms experienced at least one UTP. Our results are in line with other studies: CIAA-AIM (2011) survey revealed that 96.4\% businesses from different supply chains in the EU had encountered at least one UTP. The study of Copa-Cogeca (2013) showed that $94 \%$ of the respondents had experience with at least one UTP. Di Marcantonio, Ciaian and Castellanos (2018) reported that $93 \%$ of the farmers faced at least one of the UTPs.

One of the ways how to strengthen the bargaining position of individual farmers is their joint initiative to negotiate contract conditions and sell production through producer organisation. Almost a third of the surveyed farmers stated that being a member of a producer organisation helped them to improve their bargaining power. As seen from the study of di Marcantonio, Ciaian and Falkowski (2020) the impact of POs differs across regions. While in Germany and Poland the beneficial impact of POs seems to be the most visible, Spanish regions indicate that POs are less involved in supporting farmers to conclude contracts and increase the likelihood of farmers reporting UTPs. 
In Figure 3, we compared the incidence of unfair trade practices that occurred in relationship between primary producers and their buyers - dairy companies versus producer organizations.

Figure 3

Incidence of UTPs in Relation with Producer Organizations and Processors

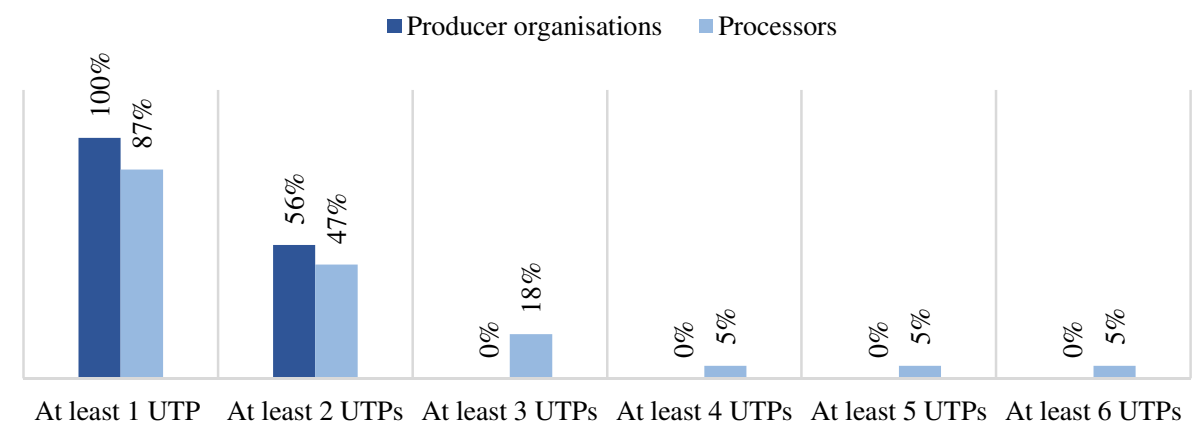

Source: Own processing.

Members of producer organizations encounter less UTPs than non-members. As seen from Figure 3, members of producer organisations faced only 1 or 2 unfair trade practices and there was no case of higher number of unfair practices. On the other hand, farms trading directly with processors reported up to six different UTPs. However, this difference has not proved to be statistically significant (Table 8). We tested the difference in average occurrence of UTPs between groups of farms trading directly with processors and farms trading via producer organizations using Mann-Whitney test for unpaired data (Prob $>|z|=0.8524$ ). Therefore, we can conclude that producer organizations do not significantly eliminate the occurrence of UTPs compared to trading directly with processors. There are several possible reasons for this conclusion. Firstly, farms in Slovakia are relatively large, which means that producer organizations are not as valuable for them as in the case of small farms. Secondly, producer organizations in Slovakia are not very efficient and they have been created not due to market forces but to draw money from the Rural Development Programme which supports the creation and activities of producer organizations (Michalek, Ciaian and Pokrivcak, 2018). Thirdly, there are not significant differences between large farms and producer organizations.

We found no statistically significant difference in the occurrence of UTPs between small farms or large farms trading with small dairies. However, when analysing the UTPs in trade relationship of big farms with small or big processors, we observe significantly more UTPs in relationship with big dairies $($ Prob $>|z|=0.05)$. 
Table 8 summarizes the two-sample Wilcoxon rank-sum (Mann-Whitney) tests designed for different pairs of farms and dairies. To conduct the test, we defined small farms with milk production less than 2 mil. litres of milk, big farms delivering more than 2 mil. litres of milk, small processor are dairies with annual sales up to 50 mil. EUR and big processors with sales more than 50 mil. EUR.

Table 8

\section{Differences in UTPs Occurrence between Different Groups of Farms}

\begin{tabular}{|c|c|c|c|}
\hline & Mean & $\mathbf{z}$ & Prob $>|z|$ \\
\hline $\begin{array}{l}\text { Members of producer organisations } \\
\text { Non-members of producer organisations }\end{array}$ & $\begin{array}{l}1.556 \\
1.684\end{array}$ & 0.186 & 0.852 \\
\hline $\begin{array}{l}\text { Small farms } \\
\text { Big farms }\end{array}$ & $\begin{array}{l}1.412 \\
1.905 \\
\end{array}$ & 0.877 & 0.381 \\
\hline $\begin{array}{l}\text { Farms trading with small processors } \\
\text { Farms trading with big processors }\end{array}$ & $\begin{array}{l}1.455 \\
1.778 \\
\end{array}$ & 0.523 & 0.601 \\
\hline $\begin{array}{l}\text { Small farms trading with small processors } \\
\text { Small farms trading with big processors }\end{array}$ & $\begin{array}{l}1.833 \\
1.182\end{array}$ & -1.314 & 0.189 \\
\hline $\begin{array}{l}\text { Big farms trading with small processors } \\
\text { Big farms trading with big processors }\end{array}$ & $\begin{array}{l}1.000 \\
2.188\end{array}$ & 1.680 & 0.093 \\
\hline $\begin{array}{l}\text { Small farms trading with big processors } \\
\text { Big farms trading with big processors }\end{array}$ & $\begin{array}{l}1.182 \\
2.188\end{array}$ & 1.953 & 0.050 \\
\hline $\begin{array}{l}\text { Small farms trading with small processors } \\
\text { Big farms trading with small processors }\end{array}$ & $\begin{array}{l}1.182 \\
1.000\end{array}$ & -1.357 & 0.175 \\
\hline
\end{tabular}

Source: Own processing.

\section{Conclusions}

This paper investigates the incidence of UTPs in trade relationships between milk producers (dairy farms) and milk processors in Slovakia. Efficient functioning of milk supply chain is strongly dependent on good relationship between farmers and processors. The situation in Slovakia is specific as Slovak dairy farms are relatively large and more diversified than dairy farms in most of the Western European Member States of the EU, therefore the analysis of UTPs in Slovak milk sector is especially interesting.

We conducted face-to-face interviews with managers of 47 dairy farms in Nitra and Trnava region. Our results show that most UTPs arise from the content of the contract between business partners. Around $81 \%$ of the farms have individual contracts with their main purchaser and $9 \%$ have contract with cooperative or producer organisation. More than half of the farmers mentioned they have 
no safeguard defined if the purchaser fails to fulfil the contract. Furthermore, 23 percent of farms did not have milk price stated in the contract. These practices became illegal after EU Directive had come into effect. During the contract execution, producers most often encountered a unilaterally changed prices by the purchaser (21.3\%) and delayed payments for milk deliveries from dairies (10.6\%). Subsequently, we asked what the producers' response to the late payments was. $80 \%$ of them did not take any action, which can be attributed to the presence of the so-called fear factor and difficulties to find new contract partner. In the context of termination of a contract, the unfair trade practice refers to the unilateral termination of the contract before expiration encountered by $6.38 \%$ of farmers. In total $89.36 \%$ of the farms experienced at least one UTP. These results are in line with Crespi, Saitone and Sexton (2012), Sexton (2013), Mérel and Sexton (2017) and di Marcantonio, Ciaian and Falkowski (2020) who found evidence that buyers do not tend to use UTPs during the contract execution, but rather implement UTPs in the contract content, at least from the farmers' perspective.

Almost third of the surveyed farmers stated that being a member of producer organisation helped them to improve their capacity of negotiation. As seen from our results, farmers who are not members of producer organisations experience more UTPs than members of producer organisations. However this difference has not proved to be statistically significant. Di Marcantonio, Ciaian and Falkowski (2020) also brought only weak evidence that POs could help alleviate UTP problems associated with more complete contracts.

The highest incidence of UTPs is observed in the group of farms delivering more than 2 mil. litres of milk per year, especially when trading with large dairies (with annual sales more than 50 mil. EUR).

\section{References}

AGRICULTURAL PAYING AGENCY (2021): Oznámenie o počtoch prvonákupcov a prvovýrobcov mlieka k 30. 06. 2021. [Cit. 16. 9. 2021.] Available at: <http://www.apa.sk/prvonakupca-mlieka>.

BASIC (2015): Banana Value Chains in Europe and the Consequences of Unfair Trading Practices. Bureau for the Appraisal of Social Impacts for Citizen Information and Fair Trade Advocacy Office Final Report, October 2015. [Cit. 14. 8. 2020.] Available at: <http://www.makefruitfair.org/wpcontent/uploads/2015/11/banana_value_chain_research_FINAL_WEB.pdf $>$.

BLOOM, P. N. - GUNDLACH, G. T. - CANNON, J. P. (2000): Slotting Allowances and Fees: Schools of Thought and the Views of Practicing Managers. Journal of Marketing, 64, No. 2, pp. 92 - 108. DOI: 10.1159/000329728.

BOEHLIJE, M. - HOFING, S. - SCHROEDER, CH. (1999): Value Chains in the Agricultural Industries. [Staff Paper \#99 - 10.] West Lafayette, IN: Purdue University Department of Agricultural Economics. 
BOLTON, P. (1990): Renegotiation and the Dynamics of Contract Design. European Economic Review, 34, No. 2 - 3, pp. $303-310$.

CIAA-AIM (2011): Survey on Unfair Commercial Practices in Europe. Dedicated, Study Commissioned by CIAA and AIM. [Cit. 14. 8. 2020.] Available at:

$<$ http://ec.europa.eu/internal_market/consultations/2013/unfairtrading-

practices/docs/contributions/registered-org/federacion-espanola-de-industrias-dealimentaciony-bebidas-fiab-2-annex_es.pdf $>$.

CIAIAN, P. - POKRIVCAK, J. - DRABIK, D. (2009): Transaction Costs, Product Specialisation and Farm Structure in Central and Eastern Europe. Post-Communist Economies, 21, No. 2, pp. 191 - 201. DOI: 10.1080/14631370902778526.

COPA-COGECA (2013): Copa-Cogeca Contribution to the Public Consultation on the Green Paper on Unfair Trading Practices (UTPs) in Business to Business (B2B) Relations in the Food and Non-Food Supply Chain. FC(13)2538:4-PG/sd, Copa-Cogeca. [Cit. 14. 8. 2020.] Available at: $<$ http://ec.europa.eu/internal_market/consultations/2013/unfairtradingpractices/docs/contributions/registered-org/copa-cogeca_en.pdf $>$.

CRESPI, J. M. - SAITONE, T. L. - SEXTON, R. J. (2012): Competition in U.S. Farm Product Markets: Do Long-run Incentives Trump Short Run Market Power? Applied Economic Perspectives and Policy, 34, No. 4, pp. $669-695$.

DAVIS, P. - REILLY, A. (2010): Market Power, Market Outcomes, and Remedies in the UK Groceries Market. Agricultural Economics, 41, No. 1, pp. 93 - 108.

DIGAL, L. N. - AHMADI-ESFAHANI, F. Z. (2002): Market Power Analysis in the Retail Food Industry: A Survey of Methods. Australian Journal of Agricultural and Resource Economics, 46, No. 4, pp. 559 - 584. DOI: 10.1111/1467-8489.00193.

Di MARCANTONIO, F. - CIAIAN, P. - CASTELlANOS, V. (2018): Unfair Trading Practices in the Dairy Farm Sector: Evidence from Selected EU Regions. EUR 29343 EN. Luxembourg: Publications Office of the European Union. ISBN 978-92-79-93164-2. DOI: 10.2760/747043.

Di MARCANTONIO, F. - CIAIAN, P. - FALKOWSKI, J. (2020): Contracting and Farmers' Perception of Unfair Trading Practices in the EU Dairy Sector. Journal of Agricultural Economics, 71, No. 3, pp. 877 - 903. DOI: 10.1111/1477-9552.12388.

EU (2019): Directive (EU) 2019/633 of the European Parliament and of the Council of 17 April 2019 on Unfair Trading Practices in Business-to-Business Relationships in the Agricultural and Food Supply Chain. Official Journal of the European Union L, 111, pp. $59-72$.

FAŁKOWSKI, J. - MENARD, C. - SEXTON, R, J. -SWINNEN, J. - VANDEVELDE, S. (2017): Unfair Trading Practices in the Food Supply Chain: A Literature Review on Methodologies, Impacts and Regulatory Aspects. Luxembourg: European Commission, Joint Research Centre. DOI: $10.2760 / 800$.

GAUDIN, G. (2016): Pass-through, Vertical Contracts, and Bargains. Economics Letters, 139, No. C, pp. 1 - 4. DOI: 10.1016/j.econlet.2015.11.043.

GOW, H. - SWINNEN, J. (2000): Impact of Foreign Direct Investment on Agriculture and Agroindustry in Transition Economies. In: CSAKI, C. and LERMAN, Z. (eds): Structural Change in the Farming Sectors in Central and Eastern Europe. [World Bank Technical Paper, No. 465.] Washington, DC: World Bank Publications.

GOW, H. - STREETER, D. - SWINNEN, J. (2000): How Private Contract Enforcement Mechanisms Can Succeed where Public Institutions Fail: The Case of Juhocukor a.s. Agricultural Economics, 23, No. 3, pp. 253 - 265. DOI: 10.1016/S0169-5150(00)00087-6.

GOW, H. - SWINNEN, J. (1998): Up- and Downstream Restructuring, Foreign Direct Investment, and Hold-up Problems in Agricultural Transition. European Review of Agricultural Economics, 25 , July, pp. $331-350$.

GUTH, M. (2016): Determinants of Milk Production in FADN Dairy Farms in the Regions of the European Union with Predominance of Intensive Production in 2011. Management, 20, No. 2, pp. 473 - 486. Available at: <https://doi.org/10.1515/manment-2015-0076>. 
HART, O. D. - TIROLE, J. (1988): Contract Renegotiation and Coasian Dynamics. The Review of Economic Studies, 55, No. 4, pp. $509-540$.

HUBERMAN, G. - KAHN, C. (1988): Limited Contract Enforcement and Strategic Renegotiation. The American Economic Review, 78, No. 3, pp. 471 - 484.

LEDERMAN, E. (1989): Criminal Liability for Breach of Confidential Commercial Information. Emory Law Journal, 38, No. 4, pp. 921 - 1004.

MacDONALD, J. M. - KEY, N. (2012): Market Power in Poultry Production Contracting? Evidence from a Farm Survey. Journal of Agricultural and Applied Economics, 44, No. 4, pp. 477 - 490.

MAGLARAS, G. - BOURLAKIS, M. - FOTOPOULOS, C. (2015): Power-imbalanced Relationships in the Dyadic Food Chain: An Empirical Investigation of Retailers' Commercial Practices with Suppliers. Industrial Marketing Management, 48, pp. 187 - 201. DOI: $10.1016 /$ j.indmarman.2015.03.014.

McCORRISTON, S. (2002): Why Should Imperfect Competition Matter to Agricultural Economists? European Review of Agricultural Economics, 29, No. 3, pp. $349-372$.

MÉREL, P. R. - SEXTON, R. J. (2017): Buyer Power with Atomistic Upstream Entry: Can Downstream Consolidation Increase Production and Welfare? International Journal of Industrial Organization, 50, No. C, pp. 259 - 293. DOI: 10.1016/j.ijindorg.2016.11.002.

MICHALEK, J. - CIAIAN, P. - POKRIVCAK, J. (2018): The Impact of Producer Organizations on Farm Performance: The Case Study of Large Farms from Slovakia. Food Policy, 75, No. C, pp. 80 - 92. DOI: I10.1016/j.foodpol.2017.12.009.

NATIONAL COUNCIL of SR (2019): Act No. 91/2019 Coll. on Unfair Conditions in the Food Trade and on Amendments to Certain Acts. [Cit. 21. 9. 2021.] Available at: <https://www.slov-lex.sk/pravne-predpisy/SK/ZZ/2019/91/>.

NATIONAL COUNCIL of SR (2021): Act No. 219/2021 Coll. an Amendment to Act No. 91/2019 Coll. On Unfair Trade Terms in the Food Trade and on Changing and Amending Certain Acts. [Cit. 21. 9. 2021.] Available at: <https://www.slov-lex.sk/pravne-predpisy/SK/ZZ/2021/219/20210615.html>.

PEREKHOZHUK, O. - GLAUBEN, T. - GRINGS, M. - TEUBER, R. (2017): Approaches and Methods for the Econometric Analysis of Market Power: A Survey and Empirical Comparison. Journal of Economic Surveys, 31, No. 1, pp. 303 - 325.

POKRIVCAK, J. - CIAIAN, P. (2004): Agricultural Reforms in Slovakia. Finance a uver - Czech Journal of Economics and Finance, 54, No. 9, pp. 420 - 435.

POKRIVCAK, J. - RAJCANIOVA, M. (2014): Price Transmission along the Food Supply Chain in Slovakia. Post-Communist Economies, Taylor \& Francis Journals, 26, No. 4, pp. 555 - 568. DOI: $10.1080 / 14631377.2014 .937111$.

REPKA, M. (2021): Komoditná situačná a výhl’adová správa Mlieko k 31. 12. 2020. Vol. XXVIII, No. 1, May 2021. Bratislava: NPPC-VÚEPP. ISSN 1338-4848.

RENDA, A. - CAFFAGI, F. - PELKMANS, J. - IAMICELI, P. - de BRITO, C. - MUSTILLI, F. - BEBBER, L. (2014): Study on the Legal Framework Covering Business-to-Business Unfair Trading Practices in the Retail Supply Chain. DG Internal Market. European Commission. DG MARKT 2012/049/E. ISBN 978-92-79-29921-6. DOI: 10.2780/91447.

RUSSO, C. - BARATHOVA, K. - CACHIARELLI, L. - Di FONZO, A. - LAI, M. - LEE, H. MENAPACE, L. - POKRIVCAK, J. - RAHBAUER, S. - RAJCANIOVA, M. - SORRENTIN, A. - SWINNEN, J. - VANDERVELDE, S. (2020): Pass-through of Unfair Trading Practices in EU Food Supply Chains: Methodology and Empirical Application. Luxembourg: Publications Office of the European Union. ISBN 978-92-76-19668-6. DOI: 10.2760/837579. JRC120994.

SEXTON, R. J. (2000): Industrialization and Consolidation in the U.S. Food Sector: Implications for Competition and Welfare, American Journal of Agricultural Economics, 82, No. 5, pp. 1087 1104.

SEXTON, R. J. (2013): Market Power, Misconceptions, and Modern Agricultural Markets. American Journal of Agricultural Economics, 95, No. 2, pp. $209-219$. 
SO SR (2021): DATAcube Database of the Statistical Office of the SR. [Cit. 16. 9. 2021.] Available at: 〈http://datacube.statistics.sk>.

SULLIVAN, M. W. (1997): Slotting Allowances and the Market for New Products. Journal of Law and Economics, 40, No. 2, pp. 461 - 494. Available at: <http://www.journals.uchicago.edu/t-and-c>.

VAVRA, P. - GOODWIN, B. K. (2005): Analysis of Price Transmission along the Food Chain. OECD Food. [Agriculture and Fisheries Working Papers, No. 3.] Paris: OECD Publishing.

VUEPP, Situation and Outlook Reports. [Cit. 12. 8. 2020.] Available at: <http://www.vuepp.sk/04_komodity.htm>.

WEVER, M. - WOGNUM, P. M. - TRIENEKENS, J. H. - OMTA, S. W. F. (2012): Supply Chain Wide Consequences of Transaction Risks and Their Contractual Solutions: Towards an Extended Transaction Cost Economics Framework. Journal of Supply Chain Management, 48, No. 1, pp. $73-91$.

\section{Appendix 1}

List of UTPs according to Directive on UTPs.

Black practices:

1. Payments later than 30 days for perishable agricultural and food products.

2. Payments later than 60 days for other agri-food products.

3. Short-notice cancellations of perishable agri-food products.

4. Unilateral contract changes by the buyer.

5. Payments not related to a specific transaction.

6. Risk of loss and deterioration transferred to the supplier.

7. Refusal of written confirmation of supply agreement by the buyer, despite request of the supplier.

8. Misuse of trade secrets by the buyer.

9. Commercial retaliation by the buyer.

10. Transferring the costs of examining customer complaints to the supplier Grey practices.

11. Return of unsold products.

12. Payment of the supplier for stocking, display and listing.

13. Payment of the supplier for promotion.

14. Payment of the supplier for marketing.

15. Payment of the supplier for advertising.

16. Payment of the supplier for staff of the buyer, fitting out premises. 


\section{Appendix 2}

List of UTPs according to the Slovak law on UTPs.

Act No. 91/2019 prohibits inappropriate conditions in the form of an agreement, in the form of requesting or applying an inappropriate condition. Inappropriate conditions are deemed to include financial and in-kind performance for

1. inclusion in the register of suppliers at the customer or the register of customers at the supplier, including changes in such register,

2. inclusion of the supplier's food in the register of food sold by the customer, including changes in such register,

3. renewal or expansion of the business network of the party to the business relationship,

4. for lower customer profit or margin than planned profit or planned customer margin,

5. a service aimed exclusively at promoting the customer,

6. a visit for the purpose of establishing a business relationship,

7. placement of food in the customer's establishment,

8. design related to the external presentation and packaging of food,

9. collection and processing of data on participants in the business relationship,

10. market research or customer data processing service performed by the customer,

11. a customer's service aimed at promoting the supplier or his foodstuff, ${ }^{2}$

12. use of customer distribution,

13. the fulfilment of a condition agreed by the parties to the business relationship concerning the removal of a certain quantity or volume of food, which is charged separately,

14. placing the food in a certain place in the customer's establishment,

15. the conclusion of a contract which does not contain specification of food supplied, the quantity, the purchase price, the method of reduction or the method of increasing the purchase price, if applicable, the time limit for payment, the service, if provided,

16. performing inspections of the supplier's premises by the customer or performing analyses and tests of the supplier's food by the customer; this does not apply if the customer carries out inspections of the supplier's premises at his own expense or analyses and tests of the supplier's

\footnotetext{
${ }^{2}$ Note that practices $11-14$ are not considered unfair if a) agreed in advance, b) agreed in written form, c) use of customer distribution is not unfair if the supplier does not have the possibility to supply food to the customer, d) total value does not exceed $6 \%$ of the supplier's turnover for food delivered to an individual customer in the relevant calendar year.
} 
food to a reasonable extent and when performing inspections of the premises also with the consent of the supplier,

17. prioritizing the results of other food quality and safety controls, nutritional data and other mandatory food information over the results of controls performed by state administration bodies pursuant to a special regulation,

18. return of food to the supplier, except in cases stipulated by the Commercial Code,

19. exchange of food at the supplier's expense, except in cases stipulated by the Commercial Code,

20. late payments, ${ }^{3}$

21. shorter time limit for the supplier's monetary performance to the customer than the agreed period for payment of the purchase price,

22. additional monetary performance or non-monetary performance after taking over the food,

23. compensation for the sanction imposed by state administration bodies to the customer,

24. compensation for monetary performance or non-monetary performance provided by the customer to the consumer,

25. non-fulfilment of the contractual obligation by the customer without a legal reason,

26. unilateral change of agreed terms, including purchase price, payment terms, volume and quality of the food delivered, specified delivery terms and conditions of service,

27. monetary payments from the supplier to the customer for loss or spoilage of food at the premises of the customer or after the acquisition of ownership of the food by the customer, which did not arise as a result of fault of the supplier,

28. advance payment for future contractual penalties,

29. conditioning the supply of food to the supplier by the production of food under the buyer's trademark,

30. refusal to indicate the supplier name on the packaging of food sold under the buyer's trademark,

31. unjustified calculation of receivables of participants in a business relationship,

\footnotetext{
${ }^{3}$ According to the (amendment) Act No. 219/2021 Coll., the due date is 30 days from the date of delivery of food, if the invoice for food is delivered to the customer within 10 days from delivery of the food or 20 days from delivery of the invoice, if the invoice was delivered to the customer after 10 days from the date of delivery of the food. For selected foods, the Amendment sets the due date within 15 days from the date of delivery of the invoice for delivery of these foods. These time periods, however, do not apply in case of payments made under the school program and to payments made by public entities providing health care.
} 
32. a different moment of acquisition of ownership of the food or a different moment of the transfer of the risk of damage to the food, such as the moment of taking over the food by the customer,

33. several contractual penalties for breach of the same contractual obligation,

34. a contractual penalty, the amount of which is disproportionate with regard to the value and significance of the breached contractual obligation,

35. the sale of food to the consumer at a lower price than the purchase price of the food delivered, except specified cases,

36. monetary payments or non-monetary payments that is not related to the subject of the contract,

37. a contractual penalty or other contractual sanction for non-delivery of goods by the supplier, if the supplier has receivables from the customer after the due date,

38. a contractual penalty or other contractual sanction for non-delivery of goods by the supplier, if no agreement is reached on the purchase price,

39. requesting a guaranteed price for a period of more than 60 days,

40. assignment of a claim conditioned by the consent of the debtor,

41. requesting a certain type of packaging that is less economically advantageous than the packaging of other suppliers of the same or similar goods,

42. any other act which deviates from fair trade,

43. transferring the costs associated with the tax burden and reducing the purchase price,

44. unauthorized acquisition, use or disclosure of trade secrets to participants in a business relationship,

45. threatening with retaliation or its practical execution if the contractual partner exercises its legal or contractual law,

46. compensation of the supplier to the customer for reviewing the consumer's submission regarding the supplier's food, if there has been no breach of the supplier's obligations. 